\title{
Estimation of the duodenal flow of microbial nitrogen in ruminants based on the chemical composition of forages: a literature review
}

\author{
Jules M.J. GosselinK ${ }^{\mathrm{a}, \mathrm{b} *}$, Claude PonCET ${ }^{\mathrm{a}}$, Jean-Pierre DuLPHY ${ }^{\mathrm{a}}$ \\ John W. CONE ${ }^{b}$ \\ a INRA, Centre de Clermont-Ferrand-Theix, Unité de Recherches sur les Herbivores, \\ 63122 Saint-Genès-Champenelle, France \\ b ID TNO Animal Nutrition, PO Box 65, 8200 AB Lelystad, The Netherlands
}

(Received 31 January 2002; accepted 11 March 2003)

\begin{abstract}
The objective of this study was to evaluate the estimation of the duodenal flow of microbial nitrogen $(\mathrm{N})$ in ruminants fed forage only, per kilogram of dry matter (DM) intake, which is the yield of microbial protein (YMP). The estimation was based on the chemical composition of forages. A data file of 62 observations was collected from in vivo studies on cattle and sheep fed diets with forage only. A statistical analysis of YMP was conducted with neutral detergent fibre (NDF), crude protein $(\mathrm{CP})$, non structural carbohydrates (NSC), group of forage species (legumes or grasses), method of conservation, physical form of presentation, level of DM intake, animal species, methodology and references as parameters. After a stepwise regression, $\mathrm{CP}$ was significant and the most important predictor. NSC or the method of conservation had an extra effect on YMP. On the basis of these three parameters the best fit equations were found and the influence of all parameters on YMP were discussed. Using the data file of this study, the prediction of YMP from the PDI-system was also validated. The statistics of the validation of the PDI prediction were similar to the statistics of the equations from this study. In conclusion, the chemical composition of forages, with or without the method of conservation, is a poor indication for the duodenal flow of microbial $\mathrm{N}\left(\mathrm{g} \cdot \mathrm{kg}^{-1} \mathrm{DM}\right.$ intake) in ruminants fed diets with forages only.
\end{abstract}

rumen / microbial nitrogen / legumes / grasses / prediction

Résumé - Estimation du flux d'azote microbien arrivant dans le duodénum à partir de la composition chimique du fourrage chez le ruminant recevant une ration composée uniquement de fourrage. L'objectif de cette revue bibliographique était d'évaluer la prévision du flux duodénal d'azote microbien chez un ruminant recevant une ration composée d'un seul fourrage, par kilogramme

\footnotetext{
* Correspondence and reprints

Tel.: + 3132023 72 88; fax: + 313202373 20; e-mail: jules.gosselink@wur.nl
} 
de matière sèche (MS) ingérée, c'est-à-dire le rendement en azote microbien (RNM). La prévision a été basée sur la composition chimique des fourrages. Un ensemble de données comprenant 62 observations a été constitué en sélectionnant les études in vivo sur bovins et moutons alimentés avec un seul fourrage. L'analyse statistique a porté sur la relation entre RNM et différents paramètres : teneur en glucides pariétaux (NDF), teneur en Matières Azotées Totales (MAT), teneur en glucides non-pariétaux (GLU), famille botanique (légumineuses ou graminées), méthode de conservation, forme physique de présentation, quantité de MS ingérée, espèce animale, méthode de mesure et références. Après la régression «stepwise », l'effet de la teneur en MAT a été significatif et le plus important. GLU comme la méthode de conservation ont eu un effet supplémentaire sur RNM. À partir de ces 3 paramètres, les équations de prédiction sont proposées. Les paramètres statistiques des équations et l'influence des différents critères de prévision du RNM sont discutés. À partir de cette base de données, la prévision du RNM du système PDI était validée aussi. Les paramètres statistiques de la validation du système PDI étaient similaires aux paramètres statistiques des équations de cette revue bibliographique. En conclusion, la composition chimique d'un fourrage, avec ou sans la méthode de conservation, est une pauvre indication pour le flux duodénal d'azote microbien (en $\mathrm{g} \cdot \mathrm{kg}^{-1} \mathrm{MS}$ ingérée) chez le ruminant recevant une ration composée uniquement de fourrage.

rumen / azote microbien / légumineuses / graminées / prévision

\section{INTRODUCTION}

The objective of this literature review was to evaluate the protein digestion in ruminants measured by in vivo experiments. This evaluation was done as a part of the revision of the feed protein evaluation system in France, PDI [62]. The amount of microbial protein synthesised in the rumen is of importance in this system and is on average $64 \%$ of the flow of protein to the duodenum in ruminants consuming forage diets. The quality of microbial protein is quite constant and high because of their amino acid profile $[9,38]$. However microbial protein flowing out of the rumen can vary, depending on factors like forage species, physiological stage, method of conservation and physical processing of forages [38].

Microbial protein flow has been predicted by the daily intake of dry matter (DM) or organic matter (OM) $[9,44,49]$ or, more precisely, based on an index of organic matter fermented in the rumen (FOM), which is used in the French PDI-system [62] and the Dutch DVE/ OEB-system [54]. However the intake of $\mathrm{DM}$ or OM is a rough predictor, FOM is estimated from $\mathrm{OM}$ digested in the total digestive tract and both predictors comprise rumen available nitrogen as well as carbohydrates.

Microbial growth depends on the amount and availability of nitrogen and energy, supplied by the non structural and structural carbohydrates in feed $[9,51]$. Structural carbohydrates can be represented by neutral detergent fibre (NDF) and has supplemental effects on microbial growth in the rumen [58]. NDF content in feed DM also affects the rate of carbohydrate digestion, which is the major factor controlling the amount of energy available for microbial growth in the rumen $[27,58]$. A lower NDF content is accompanied by higher concentrations of non structural carbohydrates (NSC) and crude protein (CP). $\mathrm{CP}$ favourably improves the efficiency of microbial growth as long as nitrogen is not limiting and protein is not used as a source of energy [9, 51].

When contributions of these different chemical components of forage DM (CP, NDF and NSC) to the synthesis of microbial protein are known, the estimation of the duodenal flow of microbial nitrogen $(\mathrm{N})$ can be made. The importance of NDF in the estimation of the duodenal flow of microbial N has been shown by Oldick et al. [44], who estimated the daily flow of microbial 
$\mathrm{N}$ to the duodenum on the base of DM intake and NDF content. Because DM intake explains the major part of the daily duodenal flow of microbial protein $[9,49]$, the prediction of this flow will be more refined when it is estimated per kilogram of DM intake.

The estimation of the duodenal flow of microbial $\mathrm{N}$ in ruminants, fed forages only, from the chemical composition of forages and in gram per $\mathrm{kg}$ of DM intake is another approach compared to the calculations of the flow of microbial $\mathrm{N}$ from the PDI- or DVE/OEB-system [54, 62]. The objective of this study was to evaluate this approach and to validate the calculations from the PDI-system, using a database from the literature. Because concentrates or ground forages have a great effect on the duodenal flow of microbial protein $[18,38]$, the selected in vivo data were from diets containing chopped or long forages only. The duodenal microbial flow per $\mathrm{kg}$ of DM intake is called hereafter the yield of microbial protein (YMP).

\section{MATERIALS AND METHODS}

\subsection{Data file generation}

A data file containing 62 observations was generated from 34 studies published during the last thirty years $[2,3,5-8,16,17$, 20,21, 24-26, 28-36, 39, 41-43, 45, 46, 52, $53,55,56,60,61]$. The 62 observations contain 27 observations with legumes (lucerne: 19 and clovers: 8 ) and 35 observations with grasses (Lolium perenne: 14, Dactylus glomerata: 4 and other grasses: 17).

The experiments with sheep and cattle with cannula in the rumen and in the abomasum or in the proximal duodenum and with a clear description of the experimental conditions were selected. All selected publications contain data of the flow of microbial $\mathrm{N}$ to the duodenum and the chemical composition of feed DM, at least $\mathrm{CP}\left(\mathrm{g} \cdot \mathrm{kg}^{-1} \mathrm{DM}\right)$ and NDF $\left(\mathrm{g} \cdot \mathrm{kg}^{-1} \mathrm{DM}\right)$. The determination of NDF was done according to the different techniques of Van Soest et al. $[23,48,58,59]$ and the determination of CP was done with the Kjeldahl method. Non structural carbohydrate (NSC, $\mathrm{g} \cdot \mathrm{kg}^{-1}$ $\mathrm{DM}$ ) was calculated as $\mathrm{OM}$ minus $\mathrm{CP}$ minus NDF. As a consequence of this calculation, NSC also comprise low concentrations of lipids [1], which have a small contribution to the energy delivered to microbial digestion [13].

Other parameters, which might have an effect on YMP and which were clearly described in the publications, were also collected for the estimation of YMP in addition to the main chemical components (CP and NDF) in the analyses (Tabs. I and II). The forages were grouped in legumes and grasses and were not represented by the forage species in the analyses because of the low numbers of data for each species. Data on the method of conservation (fresh, hay or artificially dried forage and silage), physical form of presentation (chopped or long), the level of dry matter intake (DMI, $g$ $\mathrm{DM} \cdot \mathrm{kg}^{-1}$ body weight) and animal species (sheep or cattle) were also collected. The stage of maturity, which is a characteristic of the forages, could not be used in the analyses, since it was not given precisely in the publications. However, the chemical composition of forages are well related to the stage of maturity of the forages [38].

\subsection{Description of the data file}

The chemical components ( $\mathrm{CP}, \mathrm{NDF}$ and NSC) well differentiated legumes and grasses (Tab. II). Although the ranges of these chemical components in the groups of legumes and grasses were wide, the values in the ranges were continuously distributed. However, the analysis of the difference between these two groups of forages might be biased by the parameter animal species, because experiments on legumes were mainly 
done with sheep and experiments on grasses with cattle (Tab. I).

On the contrary to the duodenal flow of non ammonia $\mathrm{N}$ per kilogram of DM intake (NAN), the duodenal flow of microbial N, expressed as YMP and as EMPS (efficiency of microbial protein synthesis: $g$ duodenal flow of microbial $\mathrm{N}$ per $\mathrm{kg}$ OM apparently digested in the rumen), was significantly different between legumes and grasses (Tab. II). The mean values of YMP and EMPS in the data file were lower for grasses than for legumes. The variation in YMP was less large than the variation in EMPS.

\subsection{Statistics}

GenStat [22] was used to statistically analyse the data file and to find the best fit equation for the estimation of YMP and NAN from the chemical composition and the other collected parameters. The parameter method of conservation (MC) contained only 2 classes, fresh forages and others, because YMP was significantly different $(P<0.05)$ between fresh forages and other methods of conservation, but no significant differences were found between the other methods of conservation in the range of NDF content of 400 to $550 \mathrm{~g} \cdot \mathrm{kg}^{-1}$
DM (Mean values for YMP $( \pm \mathrm{SE})$ were: $15.4(1.27)$ for fresh forages $(n=8), 12.0$ $(0.96)$ for hay and dried forages $(n=11)$ and $11.9(0.93)$ for silage $(n=12))$. NAN was not significantly different for these methods of conservation.

To account for the variation among experiments or studies used in the data file, the parameters methodology and references were included in the analyses. In the analysis of YMP, 4 classes of methodology were composed on the basis of the marker to measure microbial protein and on the basis of the method of measurement of the duodenal flow, with one or two flow markers and with a different type of duodenal cannula (Tab. III). In the analysis of NAN, 3 classes of methodology were composed on the basis of the measurement of the duodenal flow (Tab. III). The parameter references $(n=34)$ represent the 34 studies used in the data file.

At first the RCHECK procedure of GenStat was used to check the normal distribution of the data in the file. The correlation coefficients between the chemical components, the other parameters, YMP, NAN, DM intake per day (DMd) and the duodenal flow of microbial $\mathrm{N}$ per day (Mday) were calculated with the CORRELATE procedure.

Table I. Description of the data file: numbers of forages, legumes and grasses in each class of parameters: method of conservation, physical form of presentation and animal species.

\begin{tabular}{|c|c|c|c|c|c|c|c|c|}
\hline & \multirow[t]{2}{*}{ Total } & \multicolumn{3}{|c|}{ Method of conservation } & \multicolumn{2}{|c|}{$\begin{array}{l}\text { Physical form } \\
\text { of presentation }\end{array}$} & \multicolumn{2}{|c|}{ Animal species } \\
\hline & & Fresh & Hay/dried ${ }^{\mathrm{a}}$ & Silage & Chopped & Long & Sheep & Cattle \\
\hline & $\mathrm{n}$ & $\mathrm{n}$ & $\mathrm{n}$ & $\mathrm{n}$ & $\mathrm{n}$ & $\mathrm{n}$ & $\mathrm{n}$ & $\mathrm{n}$ \\
\hline All forages & 62 & 14 & 31 & 17 & 30 & 32 & 27 & 35 \\
\hline Legumes & 27 & 3 & 16 & 8 & 13 & 14 & 22 & 5 \\
\hline Grasses & 35 & 11 & 15 & 9 & 17 & 18 & 5 & 30 \\
\hline
\end{tabular}

${ }^{\mathrm{a}}$ Artificially dried forages. 
Table II. Description of the data file: the values of CP content $\left(\mathrm{g} \cdot \mathrm{kg}^{-1} \mathrm{DM}\right)$, NDF content $\left(\mathrm{g} \cdot \mathrm{kg}^{-1}\right.$ $\mathrm{DM})$, NSC content $\left(\mathrm{g} \cdot \mathrm{kg}^{-1} \mathrm{DM}\right), \mathrm{DMI}\left(\mathrm{g} \mathrm{DM}\right.$ intake $\left.\cdot \mathrm{kg}^{-1} \mathrm{BW}\right)$ and the values of the duodenal flow of microbial N, YMP ( $\mathrm{g} \cdot \mathrm{kg}^{-1} \mathrm{DM}$ intake) and EMPS $\left(\mathrm{g} \cdot \mathrm{kg}^{-1} \mathrm{OM}\right.$ apparently digested in the rumen $)$ and

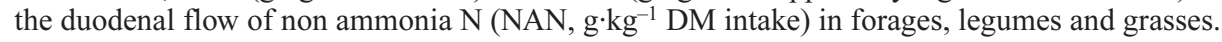

\begin{tabular}{llcccc}
\hline CP & All forages & Legumes & Grasses & $\begin{array}{c}\text { Difference } \\
\text { legume-grass }\end{array}$ \\
& Range & $50-275$ & $131-275$ & $50-250$ & \\
NDF & Mean (SE) & $159(6.8)$ & $190(8.8)$ & $137(8.8)$ & $P<0.0001$ \\
& Range & $298-845$ & $298-664$ & $331-845$ & \\
NSC & Mean (SE) & $534(18.1)$ & $458(16.8)$ & $593(25.4)$ & $P<0.0001$ \\
& Range & $23-370$ & $105-365$ & $23-370$ & \\
DMI & Mean (SE) & $210(12.3)$ & $249(10.0)$ & $180(18.9)$ & $P<0.005$ \\
& Range & $10.3-30.9$ & $10.3-30.9$ & $10.3-30.3$ & \\
YMP & Mean (SE) & $20.5(0.77)$ & $21.3(1.10)$ & $19.8(1.06)$ & NS \\
& Range & $3.4-20.8$ & $6.0-20.8$ & $3.4-18.7$ & \\
EMPS & Mean (SE) & $11.6(0.52)$ & $13.0(0.73)$ & $10.4(0.68)$ & $P<0.005$ \\
& Range & $5.4-55.9$ & $8.7-55.9$ & $5.4-50.9$ & \\
NAN & Mean (SE) & $26.3(1.35)$ & $30.7(2.10)$ & $22.8(1.55)$ & $P<0.005$ \\
& Range & $8.5-34.8$ & $8.5-33.9$ & $10.7-34.8$ & \\
\hline
\end{tabular}

${ }^{a}$ Not significant $(P>0.1)$; CP: crude protein, NDF: neutral detergent fibre, NSC: non structural carbohydrates, DMI: dry matter intake, YMP: yield of microbial protein, EMPS: efficiency of microbial protein synthesis, NAN: non ammonia N.

Candidate equations to estimate YMP were found by using stepwise regression and the FIT procedure. To reduce overparameterisation and multicollinearity in the model, two selections of predictors were done before the regression procedure. At first, the candidate models were composed from the chemical components and their quadratic terms, using the RSELECT procedure. This procedure calculates the Mallow $\mathrm{Cp}$ and selects predictors on the base of the residual sum of squares and the number of predictors. Secondly, the other parameters were added individually to the candidate models using the FIT procedure to find out which parameters and interactions could be significant in each candidate model.

$$
\begin{aligned}
\mathrm{Y}_{\mathrm{ijklmno}} & =\beta_{0}+\beta_{1} \mathrm{C}_{\mathrm{i}}+\beta_{2} \mathrm{D}_{\mathrm{j}}+\mathrm{E}_{\mathrm{k}}+\beta_{3} \mathrm{CD}_{1} \\
& +\beta_{4} \mathrm{CE}_{\mathrm{m}}+\beta_{5} \mathrm{DE}_{\mathrm{n}}+\varepsilon_{\mathrm{ijklmno}}
\end{aligned}
$$

where $\mathrm{Y}_{\mathrm{ijklmno}}=\mathrm{YMP}$ or NAN; $\mathrm{C}_{\mathrm{i}}$ or $\mathrm{D}_{\mathrm{j}}=$ chemical components, NDF (g. $\left.\mathrm{kg}^{-1} \mathrm{DM}\right)$, $\mathrm{CP}\left(\mathrm{g} \cdot \mathrm{kg}^{-1} \mathrm{DM}\right)$ or NSC $\left(\mathrm{g} \cdot \mathrm{kg}^{-1} \mathrm{DM}\right)$; $\mathrm{E}_{\mathrm{k}}=$ one of the parameters (group of forage species, method of conservation, physical form of presentation, animal species, methodology, DMI or references); $\mathrm{CD}_{1}, \mathrm{CE}_{\mathrm{m}}$ and $\mathrm{DE}_{\mathrm{n}}=$ interactions between chemical components and the added parameter; $\beta_{0 \text { to } 5}=$ regression coefficients; $\varepsilon_{\mathrm{ijklmno}}=$ residual errors.

A stepwise regression analysis of YMP and NAN was done using the candidate models with the chemical components, using the 
Table III. The description of the classes of the factor methodology used in the statistical analyses of the duodenal flow of microbial N (YMP, $\mathrm{g} \cdot \mathrm{kg}^{-1} \mathrm{DM}$ intake) and of non ammonia N (NAN, $\mathrm{g} \cdot \mathrm{kg}^{-1} \mathrm{DM}$ intake).

\begin{tabular}{|c|c|c|c|c|c|c|}
\hline Classes & Microbial marker & $\mathrm{n}$ & $\begin{array}{l}\text { Number of markers used } \\
\text { for flow measurement }\end{array}$ & & $\begin{array}{l}\text { Type of duodenal } \\
\text { cannula }\end{array}$ & $\mathrm{n}$ \\
\hline \multicolumn{7}{|l|}{ YMP } \\
\hline \multirow[t]{3}{*}{1} & Purine in digesta & 32 & One & + & Simple & 21 \\
\hline & & & One & + & Re-entrant & 9 \\
\hline & & & Two & + & Simple & 2 \\
\hline \multirow[t]{2}{*}{2} & $\begin{array}{c}\text { DAPA } \\
\text { (diaminopimelic acid) }\end{array}$ & 13 & One & + & Simple & 4 \\
\hline & & & Two & + & Simple & 9 \\
\hline \multirow[t]{2}{*}{3} & ${ }^{35} \mathrm{~S}$ (sulfur) & 10 & One & + & Re-entrant & 9 \\
\hline & & & Two & + & Simple & 1 \\
\hline 4 & $\begin{array}{l}\text { Amino acid profile, } \\
\text { RNA, Cytosine }\end{array}$ & 7 & Two & + & Simple & 7 \\
\hline \multicolumn{7}{|l|}{ NAN } \\
\hline 1 & - & & Two & + & Simple & 19 \\
\hline 2 & - & & One & + & Simple & 25 \\
\hline 3 & - & & One & + & Re-entrant & 18 \\
\hline
\end{tabular}

For abbreviations, see Table II.

parameters, which were significant in model 1, and using the parameters, which had a significant interaction with a chemical component in model 1.

$$
\begin{aligned}
& \mathrm{Y}_{\mathrm{ijklmnopqrs}}= \\
& \beta_{0}+\beta_{1} C_{i}+\beta_{2} D_{j}+E_{k}+F_{1}+\beta_{3} C D_{m} \\
& +\beta_{4} \mathrm{CE}_{\mathrm{n}}+\beta_{5} \mathrm{DE}_{\mathrm{o}}+\beta_{6} \mathrm{CF}_{\mathrm{p}}+\beta_{7} \mathrm{DF}_{\mathrm{q}} \\
& +\beta_{8} \mathrm{EF}_{\mathrm{r}}+\varepsilon_{\mathrm{ijklmnopqrs}}
\end{aligned}
$$

where $\mathrm{Y}_{\mathrm{ijklmnopqrs}}=\mathrm{YMP}$ or NAN; $\mathrm{C}_{\mathrm{i}}$ or $\mathrm{D}_{\mathrm{j}}=$ chemical components, NDF $\left(\mathrm{g} \cdot \mathrm{kg}^{-1} \mathrm{DM}\right)$, $\mathrm{CP}\left(\mathrm{g} \cdot \mathrm{kg}^{-1} \mathrm{DM}\right)$ or NSC $\left(\mathrm{g} \cdot \mathrm{kg}^{-1} \mathrm{DM}\right)$; $\mathrm{E}_{\mathrm{k}}$ or
$\mathrm{F}_{1}=$ parameters (group of forage species, method of conservation, physical form of presentation, animal species, methodology, DMI or references); $\mathrm{CD}_{\mathrm{m}}, \mathrm{CE}_{\mathrm{n}}, \mathrm{DE}_{\mathrm{o}}, \mathrm{CF}_{\mathrm{p}}$, $\mathrm{DF}_{\mathrm{q}}, \mathrm{EF}_{\mathrm{r}}=$ interactions between chemical components and parameters; $\beta_{0 \text { to } 8}=$ regression coefficients; and $\varepsilon_{\mathrm{ijklmnopqrs}}=$ residual errors.

Overparameterisation was reduced using only two-way interactions. Multicollinearity in the final candidate models was evaluated by calculating the contribution of each variable to the sum of the squares (regression).

Based on these procedures, candidate equations to estimate YMP and NAN were composed. $\mathrm{R}^{2}$ (determination coefficient) 
and the probabilities of the equations and the estimates were calculated.

The difference between the observed and predicted (estimated) flows was calculated as the mean square prediction error (MSPE), according to Bibby and Toutenberg [4]:

$$
\operatorname{MSPE}=1 / \mathrm{n} \Sigma(\mathrm{O}-\mathrm{P})^{2}
$$

$\mathrm{O}$ is the observed value and $\mathrm{P}$ is the predicted value and $\mathrm{n}$ is the number of observations. The square root of MSPE expressed as the percentage of the observed mean is used as a measure of the prediction error. MSPE was decomposed into the error in central tendency (bias), error due to regression (deviation from regression being one) and error due to disturbances (unexplained variation) [4].
These statistical parameters were used to find the best fit equations out of the candidate equations. A decreased $\mathrm{R}^{2}$ and an increased prediction error of the predictions of YMP and NAN could be expected, because of the high number of variation factors and the small number of available data.

Therefore, the best fit equations were also compared according to a method proposed by Mitchell [39]. The essence of this method is that $95 \%$ of the deviations, calculated as predicted minus observed values, are within the envelope of acceptable precision. The limits of this envelope can be defined with reference to the purpose of the model. In this study, SD (standard deviation) of YMP and NAN in the data file were used as limits. Also the limits $1.2 * \mathrm{SD}$ and $1.5 * \mathrm{SD}$ were used, because it is unreasonable to expect the model to perform as well as the in vivo data [39].

Table IV. Correlation coefficients $(P<0.05)$ between CP $\left(\mathrm{g} \cdot \mathrm{kg}^{-1} \mathrm{DM}\right), \mathrm{NDF}\left(\mathrm{g} \cdot \mathrm{kg}^{-1} \mathrm{DM}\right), \mathrm{NSC}$ $\left(\mathrm{g} \cdot \mathrm{kg}^{-1} \mathrm{DM}\right)$, DM intake (DMI, g DM intake $\left.\mathrm{kg}^{-1} \mathrm{BW}\right)$, daily DMI (DMd, g DM intake $\left.\cdot \mathrm{d}^{-1}\right)$, references (ref.), animal species (ani.), group of forage species (for.), method of conservation (MC), physical form of presentation (pre.), methodology (met.) and duodenal flow of microbial $\mathrm{N}, \mathrm{g}^{\mathrm{kg}} \mathrm{kg}^{-1} \mathrm{DM}$ intake (YMP) or $\mathrm{g}^{-\mathrm{d}^{-1}}$ (Mday) and duodenal flow of non ammonia $\mathrm{N}, \mathrm{g} \cdot \mathrm{kg}^{-1} \mathrm{DM}$ intake (NAN).

\begin{tabular}{|c|c|c|c|c|c|c|c|c|c|c|c|c|c|}
\hline & $\mathrm{CP}$ & NDF & NSC & DMI & $\mathrm{DMd}$ & ref. & ani. & for. & $\mathrm{MC}$ & pre. & met. & YMP & Mday \\
\hline $\mathrm{CP}$ & $\mathrm{x}$ & & & & & & & & & & & & \\
\hline NDF & 0.78 & $\mathrm{x}$ & & & & & & & & & & & \\
\hline NSC & 0.48 & 0.91 & $\mathrm{x}$ & & & & & & & & & & \\
\hline DMI & 0.41 & 0.53 & 0.42 & $\mathrm{x}$ & & & & & & & & & \\
\hline DMd & $\mathrm{NS}^{\mathrm{a}}$ & $N^{a}$ & $N^{a}{ }^{a}$ & 0.27 & $\mathrm{x}$ & & & & & & & & \\
\hline ref. & $\mathrm{NS}^{\mathrm{a}}$ & $\mathrm{NS}^{\mathrm{a}}$ & $\mathrm{NS}^{\mathrm{a}}$ & 0.32 & 0.35 & $\mathrm{x}$ & & & & & & & \\
\hline ani. & 0.46 & 0.39 & 0.25 & 0.14 & 0.77 & $\mathrm{NS}^{\mathrm{a}}$ & $\mathrm{x}$ & & & & & & \\
\hline for. & 0.50 & 0.46 & 0.33 & $\mathrm{NS}^{\mathrm{a}}$ & 0.56 & $\mathrm{NS}^{\mathrm{a}}$ & 0.66 & $\mathrm{x}$ & & & & & \\
\hline $\mathrm{MC}$ & 0.50 & 0.23 & 0.20 & 0.47 & 0.67 & 0.25 & 0.38 & 0.20 & $\mathrm{x}$ & & & & \\
\hline pre. & $\mathrm{NS}^{\mathrm{a}}$ & $\mathrm{NS}^{\mathrm{a}}$ & $\mathrm{NS}^{\mathrm{a}}$ & $\mathrm{NS}^{\mathrm{a}}$ & $\mathrm{NS}^{\mathrm{a}}$ & $\mathrm{NS}^{\mathrm{a}}$ & $\mathrm{NS}^{\mathrm{a}}$ & $\mathrm{NS}^{\mathrm{a}}$ & 0.35 & $\mathrm{x}$ & & & \\
\hline met. & 0.36 & 0.41 & 0.35 & 0.28 & $\mathrm{NS}^{\mathrm{a}}$ & $\mathrm{NS}^{\mathrm{a}}$ & 0.19 & $\mathrm{NS}^{\mathrm{a}}$ & 0.26 & $\mathrm{NS}^{\mathrm{a}}$ & $\mathrm{x}$ & & \\
\hline YMP & 0.50 & 0.49 & 0.41 & 0.29 & $\mathrm{NS}^{\mathrm{a}}$ & $\mathrm{NS}^{\mathrm{a}}$ & $\mathrm{NS}^{\mathrm{a}}$ & 0.29 & 0.22 & $\mathrm{NS}^{\mathrm{a}}$ & 0.25 & $\mathrm{x}$ & \\
\hline NAN & 0.60 & 0.49 & 0.30 & 0.14 & $\mathrm{NS}^{\mathrm{a}}$ & 0.29 & 0.27 & $\mathrm{NS}^{\mathrm{a}}$ & $\mathrm{NS}^{\mathrm{a}}$ & $\mathrm{NS}^{\mathrm{a}}$ & 0.41 & 0.51 & $\mathrm{NS}^{\mathrm{a}}$ \\
\hline Mday & $\mathrm{NS}^{\mathrm{a}}$ & $\mathrm{NS}^{\mathrm{a}}$ & $\mathrm{NS}^{\mathrm{a}}$ & 0.31 & 0.92 & 0.33 & 0.63 & 0.41 & 0.67 & $\mathrm{NS}^{\mathrm{a}}$ & $\mathrm{NS}^{\mathrm{a}}$ & 0.40 & $\mathrm{x}$ \\
\hline
\end{tabular}

${ }^{\text {a }}$ Not significant $(P>0.05)$; for abbreviations, see Table II. 


\section{RESULTS}

The duodenal flow of microbial $\mathrm{N}$ per day was correlated with the daily dry matter intake (Tab. IV). In the statistical analysis of this flow, the parameters, references or methodology, were significant $(P<0.05)$. These parameters were also significant $(P<0.001)$ in the analysis of NAN, which was correlated with CP (Tab. IV). Because these parameters were not significant in models to predict YMP, the results are focussed on YMP.

YMP was normal distributed and had the highest correlation coefficients with the chemical components, CP, NDF and NSC (Tab. IV). The candidate models for the estimation of YMP were based on $\mathrm{CP}$ or $\mathrm{CP}^{2}$, with or without NDF, $\mathrm{NDF}^{2}, \mathrm{NSC}$ or $\mathrm{NSC}^{2}$ (Tab. V). NDF and NSC, which were correlated, could replace each other. NSC would be more supplemental to $\mathrm{CP}$ in the prediction of YMP, because the correlation coefficient between CP and NSC was lower than between $\mathrm{CP}$ and NDF.

In the candidate models with $\mathrm{CP}^{2}$ or $\mathrm{CP}$ plus $\mathrm{CP}^{2}$ the parameter, method of conservation, tended to be significant $(P<0.1)$ (Tab. V). In the candidate models with $\mathrm{CP}$ plus $\mathrm{NSC}^{2}$ or $\mathrm{CP}^{2}$ plus $\mathrm{NSC}^{2}$ the parameter,

Table V. Candidate models with chemical components of forages, CP $\left(\mathrm{g} \cdot \mathrm{kg}^{-1} \mathrm{DM}\right)$, NDF $\left(\mathrm{g} \cdot \mathrm{kg}^{-1}\right.$ $\mathrm{DM}$ ) or NSC $\left(\mathrm{g} \cdot \mathrm{kg}^{-1} \mathrm{DM}\right)$, significant parameters (group of forage species, method of conservation, physical form of presentation, animal species, methodology, references or DMI) to predict the duodenal flow of microbial N (YMP, $\mathrm{g} \cdot \mathrm{kg}^{-1} \mathrm{DM}$ intake), significant interactions between these chemical components and parameters and the results of stepwise regression of the candidate models inclusive of the significant parameters and parameters from significant interactions.

\begin{tabular}{|c|c|c|c|}
\hline $\begin{array}{l}\text { Candidate } \\
\text { models }\end{array}$ & Significant parameters & $\begin{array}{l}\text { Significant interactions } \\
(P<0.05)\end{array}$ & $\begin{array}{l}\text { Result of stepwise } \\
\text { regression }\end{array}$ \\
\hline $\mathrm{CP}$ & & & $\mathrm{CP}$ \\
\hline $\mathrm{CP}+\mathrm{NDF}$ & & $\mathrm{NDF} *$ references & $\begin{array}{l}\mathrm{CP}+\mathrm{NDF}+\text { references } \\
+ \text { interactions }\end{array}$ \\
\hline $\mathrm{CP}+\mathrm{NSC}$ & & $\begin{array}{l}\mathrm{NSC} * \text { references } \\
\text { NSC } * \text { animal species }\end{array}$ & $\begin{array}{l}\mathrm{CP}+\mathrm{NSC}+\text { references } \\
+ \text { animal species }+ \text { interactions }\end{array}$ \\
\hline $\mathrm{CP}^{2}$ & $\begin{array}{l}\text { method of conservation } \\
(P<0.1)\end{array}$ & & $\mathrm{CP}^{2}$ \\
\hline $\mathrm{CP}+\mathrm{CP}^{2}$ & $\begin{array}{l}\text { method of conservation } \\
(P<0.1)\end{array}$ & & $\mathrm{CP}^{2}$ \\
\hline $\mathrm{CP}^{2}+\mathrm{NSC}$ & & $\begin{array}{l}\mathrm{NSC} * \text { references } \\
\mathrm{NSC} * \text { animal species }\end{array}$ & $\begin{array}{l}\mathrm{CP}^{2}+\mathrm{NSC}+\text { references }+ \\
\text { animal species }+ \text { interactions }\end{array}$ \\
\hline $\mathrm{CP}+\mathrm{NSC}^{2}$ & $\begin{array}{l}\text { group of forage species } \\
(P<0.1)\end{array}$ & $\begin{array}{l}\mathrm{NSC}^{2 *} \text { group of forage } \\
\text { species }\end{array}$ & $\begin{array}{l}\mathrm{CP}+\mathrm{NSC}^{2}+\text { interactions } \\
\text { with group of forage species }\end{array}$ \\
\hline $\mathrm{CP}^{2}+\mathrm{NSC}^{2}$ & $\begin{array}{l}\text { group of forage species } \\
(P<0.1)\end{array}$ & $\begin{array}{l}\mathrm{NSC}^{2} * \text { group of forage } \\
\text { species }\end{array}$ & $\begin{array}{l}\mathrm{CP}^{2}+\mathrm{NSC}^{2}+\text { interactions } \\
\text { with group of forage species }\end{array}$ \\
\hline $\mathrm{CP}^{2}+\mathrm{NDF}$ & & $\mathrm{NDF} *$ references & $\begin{array}{l}\mathrm{CP}^{2}+\mathrm{NDF}+\text { references } \\
+ \text { interactions }\end{array}$ \\
\hline $\mathrm{CP}+\mathrm{NDF}^{2}$ & & $\begin{array}{l}\mathrm{NDF}^{2} * \text { animal species } \\
\mathrm{NDF}^{2} * \text { methodology }\end{array}$ & $\begin{array}{l}\mathrm{CP}+\mathrm{NDF}^{2}+\text { animal species } \\
+ \text { methodology }+ \text { interactions }\end{array}$ \\
\hline $\mathrm{CP}^{2}+\mathrm{NDF}^{2}$ & & & $\mathrm{CP}^{2}$ \\
\hline
\end{tabular}

For abbreviations, see Table II. 
group of forage species, tended to be significant $(P<0.1)$, although the interactions between the group of forage species and these chemical components were significant $(P<0.05)($ Tab. V).

In all candidate models $\mathrm{CP}$ or $\mathrm{CP}^{2}$ were significant after stepwise regression (Tab. V). Most candidate models could not be used, because the parameters, references or methodology were significant after stepwise regression. These parameters were not significant in the models with $\mathrm{CP}, \mathrm{CP}^{2}, \mathrm{CP}^{2}$ plus MC, CP plus NSC ${ }^{2}$ and with $\mathrm{CP}^{2}$ plus $\mathrm{NSC}^{2}$. Neither the prediction with $\mathrm{CP}^{2}$ nor the prediction with $\mathrm{CP}^{2}$ plus $\mathrm{MC}$ or $\mathrm{NSC}^{2}$ were better than the prediction with only CP (Tab. VI). In these models, MSPE were for $100 \%$ due to the disturbance and the probability of the estimates, MC or $\mathrm{NSC}^{2}$, tended to be significant $(P<0.1)$.

Nevertheless a model with $\mathrm{CP}^{2}$ plus MC or $\mathrm{NSC}^{2}$ tended to predict YMP more precisely than a model with only $\mathrm{CP}$, because these models had a higher percentage of deviations (predicted minus observed values) within the envelope of acceptable precision with limits of $1.5 * \mathrm{SD}$ (Tab. VII, Figs. 1a and $1 b)$.
$\mathrm{CP}^{2}$ and $\mathrm{MC}$ were almost orthogonal, because the sum of the squares (regression) of the model with $\mathrm{CP}^{2}$ plus $\mathrm{MC}$ was 313 , with only $\mathrm{CP}^{2}$ was 275 and with only $\mathrm{MC}$ was 68 , as well as regression coefficients of $\mathrm{CP}^{2}$ were similar between the model with $\mathrm{CP}^{2}$ plus $\mathrm{MC}$ and the model with $\mathrm{CP}^{2}$. The parameter group of forage species did not improve the model with $\mathrm{CP}^{2}$ plus $\mathrm{NSC}^{2}$ because of multicollinearity and interactions with $\mathrm{CP}^{2}$ or $\mathrm{NSC}^{2}$.

\section{DISCUSSION}

\subsection{Duodenal flow of microbial protein and chemical components}

CP was the most important chemical component in the estimation of YMP. CP expresses the availability of $\mathrm{N}$ for the microbes in the rumen and is positively related to YMP and EMPS as long as nitrogen is not limiting and the protein is not used as a source of energy $[9,32]$. NSC had an extra effect on YMP, because of the energy supply. An increasing amount of available NSC in the rumen can prevent the use of CP as a source of energy for microbial growth.

Table VI. Candidate equations $(P<0.001)$ to estimate the duodenal flow of microbial N (YMP, $\mathrm{g}^{\mathrm{kg}} \mathrm{g}^{-1}$ DM intake) composed from candidate models and parameters in Table V.

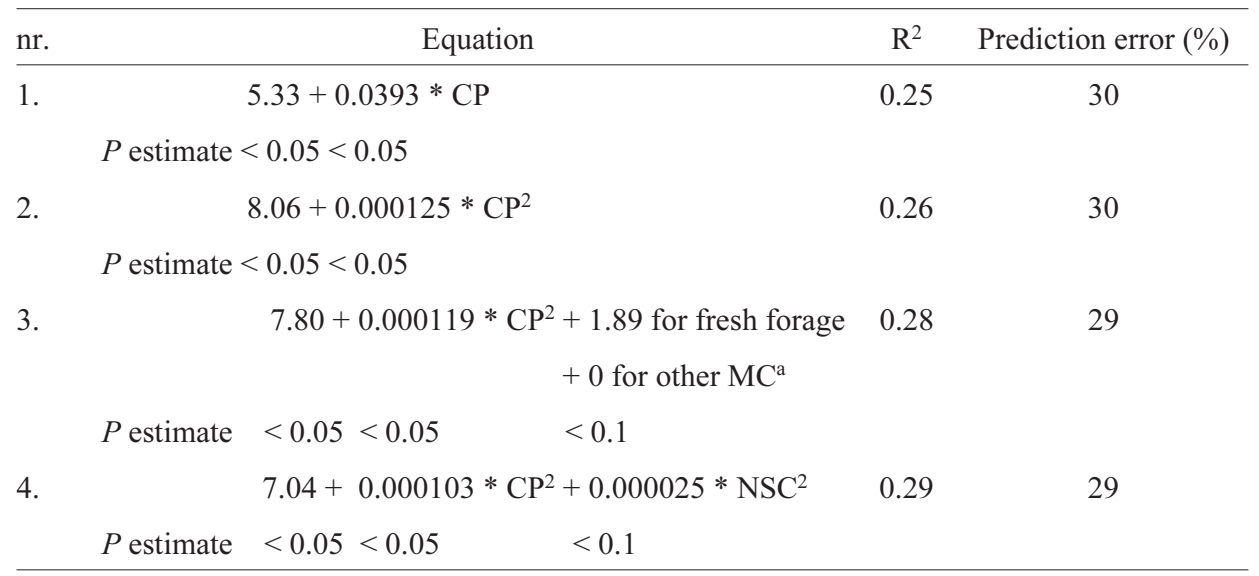

${ }^{\mathrm{a}} \mathrm{MC}=$ method of conservation; for abbreviations, see Table II. 
Table VII. Comparison of predictions of the duodenal flow of microbial N(YMP, $\mathrm{g} \cdot \mathrm{kg}^{-1}$ DM intake): equations of Table VI and the calculation from the PDI-system [(FOM*23.2 microbial $\mathrm{N}\left(\mathrm{g}^{\mathrm{kg}} \mathrm{kg}^{-1}\right.$ $\mathrm{FOM})$ )/DM intake $\left.\left(\mathrm{kg} \cdot \mathrm{d}^{-1}\right)\right]$. Comparison is based on the $\%$ of deviations (predicted flows minus observed flows) inside the envelope of acceptable precision with different limits: 4.1 (= SD of observed flows), $4.9(1.2 * \mathrm{SD})$ and $6(1.5 * \mathrm{SD})$.

\begin{tabular}{|c|c|c|c|c|}
\hline & \multirow{2}{*}{ Prediction } & \multicolumn{3}{|c|}{$\%$ of deviations inside the envelope of acceptable precision } \\
\hline & & limit $=+/-4.1$ & limit $=+/-4.9$ & limit $=+/-6.0$ \\
\hline Equation 1 & $5.33+0.0393 * \mathrm{CP}$ & 81 & 84 & 89 \\
\hline \multirow[t]{2}{*}{ Equation 3} & $\begin{array}{l}7.80+0.000119 * \mathrm{CP}^{2} \\
+1.89 \text { for fresh forage }\end{array}$ & & & \\
\hline & +0 for other $\mathrm{MC}^{\mathrm{a}}$ & 76 & 85 & 94 \\
\hline Equation 4 & $\begin{array}{c}7.04+0.000103 * \mathrm{CP}^{2} \\
+0.000025 * \mathrm{NSC}^{2}\end{array}$ & 77 & 87 & 92 \\
\hline PDI-system & $\begin{array}{l}\text { calculation from } \\
\text { the PDI-system }\end{array}$ & 75 & 82 & 86 \\
\hline
\end{tabular}

${ }^{\mathrm{a}} \mathrm{MC}=$ method of conservation; for abbreviations, see Table II; FOM: fermentable organic matter.

However, NSC can have a negative influence on the rumen function $[9,58]$. No limiting effect of NSC on YMP was found in this study, which was a consequence of the use of rations with only forages.

NSC could be replaced by NDF in the prediction of YMP. NDF is important for the rumen function and environment, because NDF does not only have a mechanical function, stimulating rumination and forming a mat in the rumen, but also a biochemical function because of the stimulation of salivation and the buffering capacity [58]. NDF had a decreasing effect on YMP, because a low concentration of NDF in dry matter coincides with a high digestibility of forages and high concentrations of NSC and CP in dry matter. Parallel to this, a low concentration of NDF in DM means a high digestion rate of NDF [49], which affects the rate of digestion of carbohydrates [58]. NDF content is also an indicator for the maturity of forages and for the difference between legumes and grasses [38].

\subsection{Duodenal flow of microbial protein and other parameters}

When MC was included in the model with $\mathrm{CP}^{2}$, the prediction of YMP was more precise. MC has different effects on the microbial protein synthesis in the rumen. The duodenal flow of microbial protein was higher for fresh forages than for other methods of conservation, which agreed with the observations of Holden et al. [26] in an experiment with dairy cows fed Orchard grass. The lower values for silage is a consequence of its lower proportions of water-soluble carbohydrates [12]. These carbohydrates are energy, which is rapidly available for the microbial growth in the rumen. The lower values for hay and dried forages may be the result of a decreased rate of ruminal degradation of dietary $\mathrm{CP}$, which diminished the availability of $\mathrm{N}$ for microbes in the rumen [38].

A group of forage species tended to have an effect on YMP, but had interactions with 

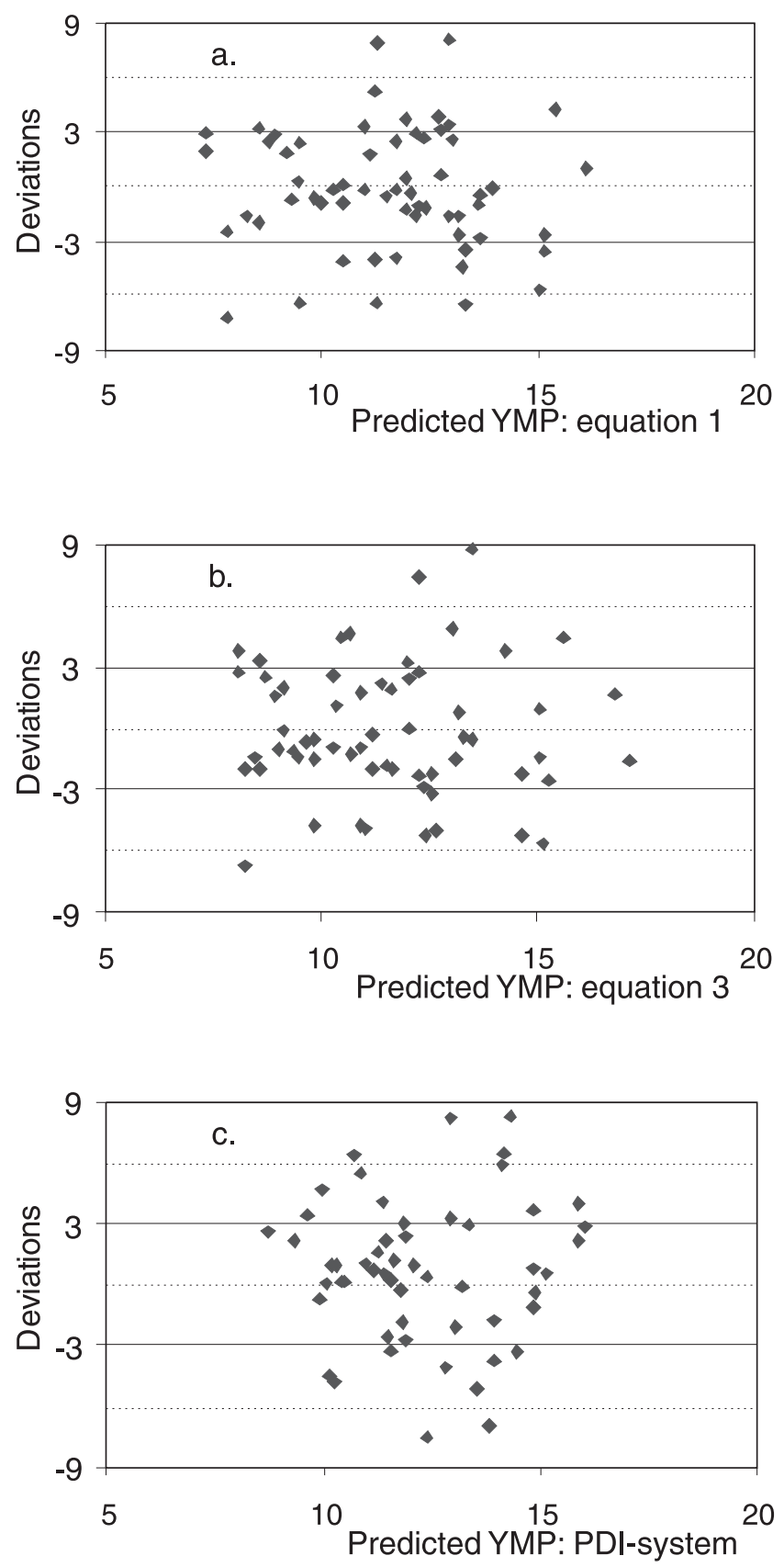

Figure 1. (a, b, c) The deviations (predicted flows minus observed flows) of the predictions of the duodenal flow of microbial N (YMP: $\mathrm{g} \cdot \mathrm{kg}^{-1} \mathrm{DM}$ intake): $\mathrm{a}$. and b., respectively, equation 1 and 3 (Tab. VII); c. the calculation from the PDI-system $\left[\left(\mathrm{FOM}^{*} 23.2\right.\right.$ microbial $\left.\mathrm{N}\left(\mathrm{g} \cdot \mathrm{kg}^{-1} \mathrm{FOM}\right)\right) / \mathrm{DM}$ intake $\left.\left(\mathrm{kg} \cdot \mathrm{d}^{-1}\right)\right] .(---=$ limits of envelope of acceptable precision: $+/-6)$. 
$\mathrm{CP}^{2}$ and $\mathrm{NSC}^{2}$. The reason for these interactions is that the content of these chemical components as well as YMP differed significantly between legumes and grasses (Tab. II). Another reason can be a different slope in the effect of CP content or NSC content on YMP between legumes and grasses, because legumes have a lower digestibility of the cell walls than grasses [38]. This difference was not significant in this study because of the small numbers in the data file.

In some models, animal species were significant in the prediction of YMP (Tab. V). These models were not useful, because references or methodology were also significant. A difference in YMP between cattle and sheep was expected, because they differ in rumen digestion and passage rates $[11,47]$.

It is noteworthy that the other parameters, which were not significant in the prediction of YMP, may also influence the rates of degradation and passage in the rumen. These parameters, such as the physical form of presentation and DMI, are known to influence microbial protein synthesis. Chopping has a positive effect on DMI through a decreased fill effect and an increased passage rate $[10,15,37]$. The efficiency of microbial protein synthesis is positively related to the rumen passage rate as a result of the reducing internal turnover of microbes and reducing maintenance cost for bacterial growth $[58,63]$. The effect of DMI on the passage rate may partly be represented by NDF in the prediction equations, since NDF content is well related to DMI and gastrointestinal fill [57]. However, the influence of chopping and DMI would have been greater, if the data file did contain diets with ground forages and no restricted DMI ( $90 \%$ of ad lib).

The parameter methodology was significant in some models. The main differences between in vivo trials originate from the variation in the methods used for measuring duodenal flow and partitioning protein in microbial versus dietary origin $[18,19,51]$. The parameter references were also significant in some models, due to the heterogeneous origin of the data.

The statistical parameters were poor, the percentages of deviations of the predictions within the envelope of acceptable precision were lower than $95 \%, \mathrm{R}^{2}$ was low and the prediction error or coefficient of variation (CV) was high. CV was about $30 \%$ and close to the CV (26.3\%) of the best fit equation of Oldick et al. [44]. This equation estimates the daily duodenal flow of microbial $\mathrm{N}$ from DMI and NDF and is composed on the basis of a data file containing 213 treatments with cattle fed mixed rations.

\subsection{Validation of the PDI-system}

The statistics of the validation of the calculation from the PDI-system [62] were compared with the statistics of the regressions from this study on the data file of the present study. The PDI calculation was composed using a data file with sheep and cattle and mixed diets and the duodenal flow of microbial $\mathrm{N}\left(\mathrm{g} \cdot \mathrm{d}^{-1}\right)$ was calculated as $\mathrm{FOM}^{*} 23.2$ microbial $\mathrm{N}\left(\mathrm{g} \cdot \mathrm{kg}^{-1} \mathrm{FOM}\right)$. FOM is fermentable OM calculated from OM digested in the total tract (DOM) minus bypass protein, volatile fatty acids and alcohol in silage, and lipids. The values of the PDI calculation were divided with the daily DM intake $\left(\mathrm{kg} \cdot \mathrm{d}^{-1}\right)$, to obtain the duodenal flow of microbial $\mathrm{N}$ per $\mathrm{kg}$ of DM intake. This calculation excludes the great effect of the daily intake of DM or OM on the daily flow of microbial N (Tab. IV).

When the values of the PDI calculation were related to the YMP values of the data file, $\mathrm{R}^{2}$ was very low $(0.10)$, the prediction error was $36 \%$ and MSPE was $92 \%$ due to disturbance. The percentage of deviations inside the envelope of acceptable precision [40] was also lower than 95\% (Tab. VII, Fig. 1c). Generally the statistics of the validation of the PDI calculation were similar 
to the statistics of the regressions from this study.

\section{CONCLUSION}

The chemical composition of forages, with or without the method of conservation, is a poor indication for the duodenal flow of microbial N per kg DM intake (YMP) in ruminants fed diets with forages only. The precision of the validation of the PDI prediction was close to the precision of the regressions of YMP from this study. The equations from this study need validations with other independent data sets.

Predicting YMP, the yield of microbial protein, is more difficult than the prediction of the daily duodenal flow of microbial protein from DM intake. The prediction of YMP partly implies EMPS, which depends on quantitative, qualitative and dynamic factors of animal and dietary origin. These factors are necessary to improve the predictions of this study and their precision. To integrate all these factors to predict the duodenal flow of microbial $\mathrm{N}$ per day or per $\mathrm{kg}$ of DM intake, mechanistic rumen models are proposed $[14,50]$.

\section{ACKNOWLEDGEMENTS}

The authors gratefully thank Dr. R. Vérité (INRA, centre de Rennes, Unité Mixte de Recherches Production du Lait, 35590 SaintGilles, France) for his scientific contributions.

\section{REFERENCES}

[1] Bauchart D., Doreau M., Legay-Carmier F., Utilisation digestive des lipides et conséquences de leur introduction sur la digestion du ruminant, Bull. Tech. CRZV Theix 61 (1985) 65-77.

[2] Beever D.E., Thomson D.J., Cammell S.B., Harrison D.G., The digestion by sheep of silages made with and without the addition of formaldehyde, J. Agric. Sci. (Camb.) 88 (1977) 61-70.
[3] Berzaghi P., Herbein J.H., Polan C.E., Intake, site, and extent of nutrient digestion of lactating cows grazing pasture, J. Dairy Sci. 79 (1996) 1581-1589.

[4] Bibby J., Toutenberg H., Prediction and improvement estimation in linear models, John Willey \& Sons, London, UK, 1977.

[5] Brake A.C., Goetsch A.L., Forster L.A. Jr., Landis K.M., Feed intake, digestion and digesta characteristics of cattle fed bermudagrass or orchardgrass alone or with ground barley or corn, J. Anim. Sci. 67 (1989) 3425-3436.

[6] Caton J.S., Erickson D.O., Carey D.A., Ulmer D.L., Influence of Aspergillus oryzae fermentation extract on forage intake, site of digestion, in situ degradability, and duodenal amino acid flow in steers grazing cool-season pasture, J. Anim. Sci. 71 (1993) 779-787.

[7] Charmley E., Veira D.M., Inhibition of proteolysis at harvest using heat in alfalfa silages: effects on silage composition and digestion by sheep, J. Anim. Sci. 68 (1990) 758-766.

[8] Charmley E., Veira D.M., Inhibition of proteolysis in alfalfa silages using heat at harvest: effects on digestion in the rumen, voluntary intake and animal performance, J. Anim. Sci. 68 (1990) 2042-2051.

[9] Clark J.H., Klusmeyer T.H., Cameron M.R., Microbial protein synthesis and flows of nitrogen fractions to the duodenum of dairy cows, J. Dairy Sci. 75 (1992) 2304-2323.

[10] Colucci P.E., Macleod G.K., Grovum W.L., McMillan I., Barney D.J., Digesta kinetics in sheep and cattle fed diets with different forage to concentrate ratios at high and low intakes, J. Dairy Sci. 73 (1990) 2143-2156.

[11] Colucci P.E., Macleod G.K., Grovum W.L., Cahill L.W., McMillan I., Comparative digestion in sheep and cattle fed different forage to concentrate ratios at high and low intakes, J. Dairy Sci. 72 (1989) 1774-1785.

[12] Demarquilly C., Fertilisation et qualité du fourrage, Fourrages 69 (1977) 61-84.

[13] Demeyer D., Van Nevel C., Influence of substrate and microbial interaction on efficiency of rumen microbial growth, Reprod. Nutr. Dév. 26 (1986) 161-179.

[14] Dijkstra J., Neal H.D., Beever D.E., France J., Simulation of nutrient digestion, absorption and outflow in the rumen: model description, J. Nutr. 122 (1992) 2239-2256.

[15] Djouvinov D.S., Todorov N.A., Influence of dry matter intake and passage rate on microbial protein synthesis in the rumen of sheep and its estimation by cannulation and a non-invasive method, Anim. Feed Sci. Technol. 48 (1994) 289-304.

[16] Elizalde J.C., Merchen N.R., Faulkner D.B., Supplemental cracked corn for steers fed fresh alfalfa. I. Effects on digestion of organic matter, 
fiber, and starch, J. Anim. Sci. 77 (1999) 457-466.

[17] Elizalde J.C., Merchen N.R., Faulkner D.B., Supplemental cracked corn for steers fed fresh alfalfa. II. Protein and amino acid digestion, J. Anim. Sci. 77 (1999) 467-475.

[18] Faichney G.J., Digesta flow, in: Forbes J.M., France J. (Eds.), Quantitative aspects of ruminant digestion and metabolism, CAB International, Wallingford, UK, 1993, pp. 53-85.

[19] Firkins J.L., Allen M.S., Oldick B.S., St-Pierre N.R., Modeling ruminal digestibility of carbohydrates and microbial protein flow to the duodenum, J. Dairy Sci. 81 (1998) 3350-3369.

[20] Galloway D.L. Sr., Goetsch A.L., Forster L.A. Jr., Brake A.C., Johnson Z.B., Digestion, feed intake, and live weight gain by cattle consuming bermudagrass and supplemented with different grains, J. Anim. Sci. 71 (1993) 1288-1297.

[21] Galloway D.L. Sr., Goetsch A.L., Sun W., Forster L.A. Jr., Murphy G.E., Grant E.W., Johnson Z.B., Digestion, feed intake, and live weight gain by cattle consuming bermudagrass hay supplemented with whey, J. Anim. Sci. 70 (1992) 2533-2541.

[22] Genstat, Reference manual, Release 5.2. VSN International, Oxford, UK, 2000.

[23] Goering H.K., Van Soest P.J., Forage fiber analyses, Agricultural Handbook No. 379, US Department of Agriculture, Washington, DC, 1970, pp. 1-20.

[24] Goetsch A.L., Forster L.A. Jr., Murphy G.E., Grant E.W., Galloway D.L. Sr., West C.P., Digestion and live-weight gain by beef cattle consuming bermudagrass supplemented with grain or different high-protein foodstuffs, Anim. Prod. 51 (1990) 263-275.

[25] Hogan J.P., Lindsay J.R., The digestion of nitrogen associated with plant cell wall in the stomach and small intestine of the sheep, Aust. J. Agric. Res. 31 (1979) 147-153.

[26] Holden L.A., Muller L.D., Varga G.A., Hillard P.J., Ruminal digestion and duodenal nutrient flows in dairy cows consuming grass as pasture, hay, or silage, J. Dairy Sci. 77 (1994) 3034-3042.

[27] Hoover W.H., Stokes S.R., Balancing carbohydrates and proteins for optimum rumen microbial yield, J. Dairy Sci. 74 (1991) 3630-3644.

[28] Hume I.D., Purser D.B., Ruminal and postruminal protein digestion in sheep fed on subterranean clover harvested at four stages of maturity, Aust. J. Agric. Res. 26 (1975) 199-208.

[29] Jones A.L., Goetsch A.L., Effects of dietary forage proportion on digestive function in maintenance-fed beef cows. 1. Fescue and clover hays, Arch. Anim. Nutr. 37 (1987) 685-699.

[30] Jones A.L., Goetsch A.L., Stokes S.R., Effects of dietary forage proportion on digestive function in maintenance-fed beef cows. 2. Fescue and bermudagrass hays, Arch. Anim. Nutr. 37 (1987) 701-711.

[31] Jones A.L., Goetsch A.L., Stokes S.R., Coldberg M., Effects of dietary forage proportion on digestive function in maintenance-fed beef cows. 3. Bermudagrass and clover hays, Arch. Anim. Nutr. 37 (1987) 1009-1020.

[32] Kawas J.R., Jorgensen N.R., Lu C.D., Influence of alfalfa maturity on feed intake and site of nutrient digestion in sheep, J. Anim. Sci. 68 (1990) 4376-4386.

[33] Krysl L.J., Branine M.E., Cheema A.U., Funk M.A., Galyean M.L., Influence of soybean meal and sorghum grain supplementation on intake, digesta kinetics, ruminal fermentation, site and extent of digestion and microbial protein synthesis in beef steers grazing blue grama rangeland, J. Anim. Sci. 67 (1989) 3040-3051.

[34] Krysl L.J., Judkins M.B., Bohman V.R., Influence of ruminal or duodenal soybean oil infusion on intake, ruminal fermentation, site and extent of digestion, and microbial protein synthesis in beef heifers consuming grass hay, J. Anim. Sci. 69 (1991) 2585-2590.

[35] Lindsay J.R., Hogan J.P., Digestion of two legumes and rumen bacterial growth in defaunated sheep, Aust. J. Agric. Res. 23 (1972) 321-330.

[36] Makoni N.F., von Keyserlingk M.A.G., Shelford J.A., Fisher L.J., Degradability of frozen and ensiled alfalfa proteins by sheep and assessment of duodenal digesta protein, Anim. Feed Sci. Technol. 53 (1995) 221-231.

[37] Malbert C.H., Baumont R., The effects of intake of lucerne (Medicago sativa L.) and orchard grass (Dactylis glomerata L.) hay on the motility of the forestomach and digesta flow at the abomaso-duodenal junction of the sheep, Brit. J. Nutr. 61 (1989) 699-714.

[38] Merchen N.R., Bourquin L.D., Process of digestion and factors influencing digestion of forage-based diets by ruminants, in: Fahey G.C. Jr. (Ed.), Forage quality, evaluation, and utilization, ASA, CSSA, SSSA, Madison, WI, USA, 1994, pp. 564-612.

[39] Merchen N.R., Satter L.D., Digestion of nitrogen by lambs fed alfalfa conserved as baled hay or as low moisture silage, J. Anim. Sci. 56 (1983) 943-951.

[40] Mitchell P.L., Misuse of regression for empirical validation of models, Agric. Syst. 54 (1997) 313-326.

[41] Muntifering R.B., Wedekind K.J., Knifley T., Ely D.G., Effects of processing on the supplemental protein value of distillers byproducts in forage diets, J. Anim. Sci. 61 (1985) 647-653.

[42] Narasimhalu P., Teller E., Vanbelle M., Foulon M., Dasnoy F., Apparent digestibility of nitrogen in rumen and whole tract of friesian cattle fed direct-cut and wilted grass silages, J. Dairy Sci. 72 (1989) 2055-2061. 
[43] O’Mara F.P., Stakelum G.K., Dillon P., Murphy J.J., Rath M., Rumen fermentation and nutrient flows for cows fed grass and grass supplemented with molassed beet pulp pellets, J. Dairy Sci. 80 (1997) 2466-2474.

[44] Oldick B.S., Firkins J.L., St-Pierre N.R., Estimation of microbial nitrogen flow to the duodenum of cattle based on dry matter intake and diet composition, J. Dairy Sci. 82 (1999) 1497-1511.

[45] Perez J.F., Balcells J., Guada J.A., Castrillo C., Determination of rumen microbial-nitrogen production in sheep: a comparison of urinary purine excretion with methods using $15 \mathrm{~N}$ and purine bases as markers of microbial-nitrogen entering the duodenum, Brit. J. Nutr. 75 (1996) 699-709.

[46] Peyraud J.L., Astigarraga L., Faverdin P., Digestion of fresh perennial ryegrass fertilized at two levels of nitrogen by lactating dairy cows, Anim. Feed Sci. Technol. 64 (1997) 155-171.

[47] Poncet C., Michalet-Doreau B., McAllister T., Rémond D., Dietary compounds escaping rumen digestion, in: Journet M., Grenet E., Farce M.-H., Thériez M. (Eds.), Recent developments in the nutrition of herbivores, INRA éditions, Paris, France, 1995.

[48] Robertson J.B., Van Soest P.J., The detergent system of analysis and its application to human foods, in: James W.P.T., Theander O. (Eds.), The analysis of dietary fiber in food, Marcel Dekker, New York, USA, 1981, pp. 123-158.

[49] Sauvant D., Grenet E., Doreau M., Dégradation chimique des aliments dans le réticulo-rumen: cinétique et importance, in: Jarrige R., Ruckebusch Y., Demarquilly C., Farce M.-H., Journet M. (Eds.), Nutrition des ruminants domestiques - Ingestion et digestion, INRA éditions, Paris, France, 1995, pp. 383-406.

[50] Sauvant D., Dijkstra J., Mertens D., Optimisation of ruminal digestion: a modelling approach, in: Journet M., Grenet E., Farce M.-H., Thériez M. (Eds.), Recent developments in the nutrition of herbivores, INRA éditions, Paris, France, 1995.

[51] Stern M.D., Varga G.A., Clark J.H., Firkins J.L., Huber J.T., Palmquist D.L., Evaluation of chemical and physical properties of feeds that affect protein metabolism in the rumen, J. Dairy Sci. 77 (1994) 2762-2786.

[52] Stokes S.R., Goetsch A.L., Jones A.L., Landis K.M., Feed intake and digestion by beef cows fed prairie hay with different levels of soybean meal and receiving postruminal administration of antibiotics, J. Anim. Sci. 66 (1988) 1778-1789.
[53] Stokes S.R., Goetsch A.L., Landis K.L., Feed intake and digestion by beef steers consuming and receiving ruminal insertions of prairie hay differing in level and particle size, J. Anim. Sci. 66 (1988) 1267-1274.

[54] Tamminga S., Van Straalen W.M., Subnel A.P.J., Meijer R.G.M., Steg A., Wever C.J.G., Blok M.C., The Dutch protein evaluation system: the DVE/OEB-system, Livest. Prod. Sci. 40 (1994) 139-155.

[55] Thompson D.J., Beever D.E., Lonsdale C.R., Haines M.J., Cammell S.B., Austin A.R., The digestion by cattle of grass silage made with formic acid and formic acid-formaldehyde, Brit. J. Nutr. 46 (1981) 193-207.

[56] Tjandraatmadja M., MacRae I.C., Norton B.W., Digestion by sheep of silages prepared from mixtures of tropical grasses and legumes, J. Agric. Sci. (Camb.) 120 (1993) 407-415.

[57] Van Soest P.J., Nutritional ecology of the ruminant, Cornell University Press, New York, USA, 1982.

[58] Van Soest P.J., Robertson J.B., Lewis B.A., Methods for dietary fiber, neutral detergent fiber, and nonstarch polysaccharides in relation to animal nutrition, J. Dairy Sci. 74 (1991) 3583-3597.

[59] Van Soest P.J., Wine R.H., Use of detergents in the analysis of fibrous feeds. IV. Determination of plant cell wall constituents, J. Assoc. Off. Anal. Chem. 50 (1967) 50-55.

[60] Van Vuuren A.M., Krol-Kramer F., van der Lee R.A., Corbijn H., Protein digestion and intestinal amino acids in dairy cows fed fresh Lolium perenne with different nitrogen contents, J. Dairy Sci. 75 (1992) 2215-2225.

[61] Varel V.H., Kreikemeier K.K., Influence of feeding Aspergillus oryzae fermentation extract (Amaferm) on in situ fiber degradation, ruminal fermentation, and microbial protein synthesis in nonlactating cows fed alfalfa or bromegrass hay, J. Anim. Sci. 72 (1994) 1814-1822.

[62] Vérité R., Michalet-Doreau B., Chapoutot P., Peyraud J.-L., Poncet C., Révision du système des protéines digestibles dans l'intestin (P.D.I.), Bull. Tech. CRZV Theix 70 (1987) 19-34.

[63] Walker D.J., Egan A.R., Nader C.J., Ulyatt M.J., Storer G.B., Rumen microbial protein synthesis and proportions of microbial and non-microbial nitrogen flowing to the intestines of sheep, Aust. J. Agric. Res. 26 (1975) 609-708. 